\title{
RODILLA ROTA
}

Luis Enrique Palma

(C) UNAN-Managua

Recibido: abril 2018

Aprobado: junio 2018

(c) (†)

Katherine lloraba a escondidas cerca de los baños del colegio. Sollozaba sin temor a que la mirasen, con entera libertad, como los aborígenes destilaban océanos en los inicios del mundo. Aparentemente nadie la observaba, ni siquiera los profesores que solían vigilar esos alrededores. Todos, estudiantes y maestros, reunidos en la plaza principal de la escuela, preferían festejar el campeonato de futbol recién conseguido por su colegio, antes que pensar en Katherine, quien, según ellos, casi les arruina la celebración por culpa de sus múltiples errores. Pese a tratarse de la jugadora emblema del equipo, anotadora de goles decisivos en el intercolegial, Katherine había marcado en propia puerta durante esa final celebrada en nuestra escuela. Su desempeño fue pésimo durante el partido, vaya a saber uno por qué, hasta el punto que el entrenador, temiendo que los estudiantes nos tomáramos la cancha, la sustituyó durante al finalizar la primera mitad.

Mis compañeros, con memoria de lagartija, habían olvidado las proezas de Katherine en partidos anteriores, al igual que ella se había desentendido de sus pies y la pelota. No se guardaban ningún insulto, le dijeron de todo mientras la veían resbalar con el balón en la primera mitad. Me extrañó que no hubiese llorado ante la mirada carnicera de todos; en aquel entonces, hace un par de décadas, ella era apenas una adolescente, vulnerable a la tristeza como cualquiera de su edad.

Que yo recuerde en ningún minuto de ese primer tiempo se derrumbó ante la angustia y la frustración. Su carácter, imponente en las victorias de su equipo, tampoco aflojaba en los malos momentos, al menos eso se advertía a primera impresión.

Entenderán, por tanto, que tenía mis razones para enamorarme de Katherine. No solo yo, casi todos en el colegio admirábamos su temperamento. También se justifica que me haya molestado con el entrenador-con el mundo en general- por haberla sustituido. A diferencia de mis compañeros, e incluso de mis profesores, yo no había desechado a Katherine del partido. Seguía creyendo en su talento. Pensaba que en cualquier momento de la segunda mitad, si se lo proponía y se libraba de la mala suerte, ella revertiría el marcador; aunque bien, debo ser franco, su presencia no fue necesaria para que nuestro equipo ganase.

A minutos de reanudarse el partido, cuando Katherine, enfurecida, se había aislado de la gente, sus compañeras marcaron un gol, y luego otro, y otro, hasta terminar ganando por goleada. Fue memorable, al menos eso decían mis compañeros, pues yo, la verdad, me acuerdo muy poco de ese segundo tiempo.

Creo recordar que ni celebré las anotaciones, mi pensamiento solo divagaba sobre Katherine. Me preocupaba lo que le había sucedido, cuestionándome por qué, en el partido más transcendental, había dejado de ser la futbolista de siempre. 
En el fondo, más que afligirme el resultado del partido, me preocupaba que Katherine hubiese cambiado de la noche a la mañana, con la misma fugacidad con que Ronaldo -lo digo con mucho respeto- descuidó sus tacones mágicos para mutar, casi sin que nos diésemos cuenta, en un gordito de rótula quebrada.

Temía que Katherine sufriese una mutación similar a la de Ronaldo. Cuando terminó el partido, decidí buscarla entre los rincones del colegio, sin importar que nunca le hubiese compartido alguna palabra. Pese a mi admiración, yo no la conocía en persona, jamás le había dicho alguna frase; sabía de su existencia gracias a los comentarios que escuchaba sobre ella en los pasillos. Para mí significaba, por tanto, un ideal similar a las aspiraciones futbolísticas que siguen los hinchas, a la altura de los regates de Ronaldo en la Copa del Mundo. Un ideal que, en ese momento, podría estar a mi alcance.

Encontré a Katherine, como creo haber dicho, cerca de los baños del colegio, ocultándose de cualquier rastro humano. Lloraba casi sin respirar, al borde de la asfixia. Se había extinto su carácter áspero e imbatible, si es que en realidad existió alguna vez. Me limité a verla desde la distancia, cuestionándome por qué, si nuestro colegio había ganado el campeonato, ella no paraba de llorar. ¿Acaso no se había enterado del triunfo de sus compañeras? Tomando en cuenta su estado solitario en ese momento, distanciado de la fiesta, nadie pudo haberle informado sobre el resultado del partido.

Estaba claro que desconocía la victoria de su equipo, de lo contrario su llanto hubiese cesado y su mirada desganada y empapada hubiera desaparecido. En sus lágrimas, al parecer, se descoloraba el ensueño de su mirada, su singularidad. Me atrevo a decir que su llanto la convertía en una criatura idéntica a nosotros, el resto de la humanidad. Todo aquello era una lástima. Frente a mí se derrumbaba la idealización que había construido durante aquella temporada, en sus ojos, tristes y palpables, observaba la rodilla rota de Ronaldo, los vómitos de Messi, las piernas desgastadas de Puyol, en fin.

Comprendí por qué Katherine había estado conteniendo su llanto en la cancha, no quería que su inmortalidad fuese ultrajada ante los entrometidos. Por lo mismo, preferí omitir este incidente ante mis compañeros para no dañar la imagen de Katherine. Tampoco se lo comenté a ella, en parte porque los residuos de mi enamoramiento prevalecían la timidez y la impotencia. Ni siquiera le señalé que nuestro colegio había ganado el campeonato, a fin de que recuperase sus ánimos y, muy probablemente, su mirada.

A pesar de que, pasados los meses, ella volvió a anotar goles y protagonizar los partidos de su equipo, sus ojos no se deshicieron del aire compasivo, no dejaron de reflejarme residuos de piernas y rodillas. Desde esa vez que observé su desencanto a escondidas, Katherine dejó de ser la misma para mí. Su mirada perdió viveza.

A menudo creía que nadie le había informado sobre la victoria de su equipo, como remedio para volviese a ser la de antes. Ni sus amigas ni el entrenador le hablaron de la goleada en el segundo tiempo, de la fiesta luego del partido, de todo eso. Nadie se apiadó de su tristeza. Así transcurrió toda su secundaria, es la fecha y la cosa no ha cambiado mucho. 
Hace un par de días, de camino a trabajo, me encontré con Katherine a la espera de un taxi. Me excité un poco con la idea de rencontrarme con el pasado, por lo que me acerqué para observarla con más detalle, aunque siguiese sin conocerme. Alcancé a fijarme en su mirada, de la cual aún no me había olvidado por completo. Era triste y desganada, como la de cualquier otro ser humano, idéntica a la de aquella tarde que lloraba a escondidas. Al parecer seguía sin enterarse de la hazaña de sus compañeras. Me inspiró un poco de lástima. Habían transcurrido unos cuantos años, con quién sabe cuántas vivencias, y ella seguía sufriendo las penas del pasado.

En esta oportunidad, motivado más que todo por la compasión, decidí decirle la verdad de una vez por todas. Cuando le hablase del triunfo de nuestro colegio, yo podría idealizarla de nuevo, a diferencia de lo que ha ocurrido con Ronaldo, Messi y Puyol. Sin embargo, al contemplar la posibilidad de que ya estuviese enterada del asunto, vacilé en mi decisión. Y si aun sabiéndola, prefirió ignorar la verdad para no transformarse en quien fue en un inicio; y si se hizo la desentendida a propósito, queriendo evitar el sobrepeso de lo sobrenatural; y si ha apreciado más el residuo de su mirada antes que su antiguo par de ojos imponentes; y si los futbolistas lastiman sus rodillas por sí mismo... En lo que yo pensaba esto, Katherine se marchó en taxi con toda y su mirada, con la rótula de Ronaldo, el estómago de Messi, las piernas de Puyol y mi aprecio por el fútbol. 